\title{
ROOT ENDOPHYTIC FUNGI PROMOTE IN VITRO SEED GERMINATION IN PLEUROTHALLIS CORIACARDIA (ORCHIDACEAE)
}

\author{
Gabriela P. Maldonado ${ }^{1}$, Luis A. Yarzábal ${ }^{2}$, Juan M. Cevallos-Cevallos ${ }^{3}$, \\ Eduardo J. ChicA ${ }^{1} \&$ Denisse F. Peña ${ }^{1,4}$ \\ ${ }^{1}$ Facultad de Ciencias Agropecuarias, Universidad de Cuenca, Campus Yanuncay, \\ Av. 12 de octubre y Diego de Tapia, Cuenca, Ecuador \\ ${ }^{2}$ Unidad de Salud y Bienestar, Universidad Católica de Cuenca, \\ Av. Las Américas y Calle Humboldt, Cuenca, Ecuador \\ ${ }^{3}$ Escuela Superior Politécnica del Litoral, ESPOL, Centro de Investigaciones Biotecnológicas \\ del Ecuador (CIBE), Campus Gustavo Galindo Km. 30.5 Vía Perimetral, \\ P.O. Box 09-01-5863, Guayaquil, Ecuador \\ ${ }^{4}$ Corresponding author: denisse.pena@ucuenca.edu.ec
}

\begin{abstract}
AвSTRACT. Seeds of many orchids rely on the presence of fungi to trigger the germination process and even to initiate the full development of protocorms. While attention has been directed towards the study of mycorrhizal fungi, the diversity and functions of endophytic fungi from orchid roots remain underexplored, and few studies have verified their ecological role. This is the case of Pleurothallis coriacardia, an endemic green Neotropical orchid with both epiphytic and lithophytic habits growing in High-Andean montane forests. In the present study, we screened the cultivable fraction of the endophytic fungi colonizing the roots of mature plants of $P$. coriacardia using ITS rDNA markers. We also tested the potential of these endophytic fungi to improve embryo development and seed germination. Most of the isolated endophytes were classified within Psathyrellaceae. Some isolates, identified as members of the Ilyonectria and Coprinellus genera, significantly promoted embryo development in vitro in $P$. coriacardia seeds, a result that highlights the ecological roles these endophytic fungi may play in nature.

RESUMEN. Las semillas de la mayor parte de orquídeas dependen de la presencia de hongos para desencadenar el proceso de germinación e incluso el desarrollo de protocormos. Mientras la atención se ha dirigido hacia el estudio de los hongos micorrícicos con este fin, la diversidad y las funciones de otros hongos endófitos que habitan las raíces de orquídeas siguen siendo poco conocidas, y pocos estudios han verificado un rol ecológico en beneficio de la planta. Este es el caso de Pleurothallis coriacardia una orquídea endémica de bosques montanos de los Andes, con hábitos epífitos y litófitos. En el presente estudio, se aisló la fracción cultivable de hongos endófitos de especímenes maduros de $P$. coriacardia, mediante amplificación por PCR y secuenciación de la región ITS. Además se evaluó el potencial de 15 aislados seleccionados en ensayos preliminares como promotores de la germinación, analizando la tasa de cada estado de desarrollo de las semillas en presencia de cada hongo. Se logró identificar 134 cepas de hongos endófitos, con una elevada frecuencia de géneros pertenecientes a la familia Psathyrellaceae. En los ensayos de germinación, cepas identificadas como Ilyonectria sp. y Coprinellus sp., promovieron significativamente el desarrollo embrionario in vitro en semillas de $P$. coriacardia, un resultado que resalta uno de los posibles roles ecológicos que estos hongos endófitos pueden jugar en la naturaleza.

Keywords/Palabras clave: Andean montane forest, bosques montanos andinos, desarrollo embrionario, embryo development, epiphytic orchids, Ilyonectria, lithophytic orchids, orquídeas epífitas, orquídeas litófitas, Psathryrellaceae
\end{abstract}

Introduction. Symbiotic relationships between fungi and plants have drawn the attention of scientists since their initial description 140 years ago (De Bary 1879). Countless investigations have confirmed that most, if not all, plant species in natural ecosystems establish symbiotic relationships with endophytic microorganisms (Sun \& Guo 2012). This diverse group of endophytes includes both fungi and bacteria, which are able to colonize the inner tissues of their plant hosts without causing any apparent damage (Bayman \& Otero 2006, Bonfante \& Anca 2009). The interactions established between endophytic microorganisms and plants can range from mutualism to saprophytism and have influenced the ecology, survival, and evolution of the host plants. 
Endophytes seem to play a very important role in maintaining the structure and diversity of the plant community and, consequently, of the entire ecosystem (Laforest-Lapointe et al. 2017, Tao et al. 2008). However, despite their potential roles as promoters of orchid germination and development, endophytes have rarely been studied (Ma et al. 2015). This is striking considering the diversity of this group of microorganisms, containing over 110 genera, and the potential functional roles played by these fungi, among which stand out the promotion of seed germination and protocorm development in plants (Pant et al. 2017, Teixeira da Silva et al. 2015, Tsavkelova et al. 2008).

Regardless of being an old and highly specialized group, the Orchidaceae family still displays diversification and speciation processes (Otero, Ackerman \& Bayman 2002, Zettler, Sharma \& Rasmussen 2003). Orchid development depends on the establishment of symbiotic associations with fungi, which provide a source of nutrients, particularly during seed germination - a behavior known as mycoheterotrophy (Kottke et al. 2013, Riofrío et al. 2013, Yoder, Zettler \& Stewart 2000, Zettler et al. 2003).

Pleurothallis coriacardia is a green orchid found in the high Andes of South America, which shows both epiphytic and lithophytic habits. According to CITES (Convention on International Trade in Endangered Species of Wild Fauna and Flora), Pleurothallis spp. commercialization should obey strict commerce regulations (CITES 1992). However, many of these orchid species are extracted from their natural environments and marketed illegally (Jiménez 2014, Pant et al. 2017), with only a few companies dedicated to their reproduction for commercial purposes. An effective alternative to avoid illegal extraction of orchids is their controlled propagation for horticultural purposes using germination media enriched with simple sugars and nutrients, such as Phytamax ${ }^{\mathrm{TM}}$ and Murashige \& Skoog (1962). However, it is also possible to take advantage of the natural functions played by endophytic fungi for orchid propagation and conservation purposes (Sharma et al. 2002).

Information concerning P. coriacardia ecology, distribution, and symbiotic relationships is scarce (Suárez et al. 2006, 2008, Suárez \& Kottke 2016). Even though no experimental results are currently available, Pleurothallis spp. are considered very challenging to reproduce and grow under controlled conditions. Indeed, it has been shown that Pleurothallis spp. are dependent on insect pollination to achieve successful fruit development and to attain high seed viability, with reports of high inbreeding depression in natural populations (Borba, Semir \& Shepherd 2001) and limited sexual reproduction (CaraDona \& Ackerman 2012).

Seeking to understand more about the ecological relationship between endophytes and epiphytic orchids, this work aimed to characterize endophytic fungi that naturally colonize the roots of $P$. coriacardia and to evaluate the endophytes potential as promoters of $P$. coriacardia seed germination in vitro.

\section{Materials and methods}

Study site.- Samples were collected in the Mazán Forest Reserve, located about $10 \mathrm{~km}$ east of the city of Cuenca (Azuay Province, Ecuador), at $02^{\circ} 50^{\prime} \mathrm{S}$ and $79^{\circ} 13^{\prime} \mathrm{W}$ (Fig. 1). This forest reserve occupies a total area of 2640 ha, ranging from 2800 to $3500 \mathrm{~m}$ in elevation. The annual precipitation in this region varies between 1000 and $2000 \mathrm{~mm}$, with a temperature range between 6 and $12^{\circ} \mathrm{C}$. Mazán Reserve is representative of the evergreen high montane forests and contains about 300 species of vascular plants, among which are 40 species of epiphytes, including orchids and bromeliads (Guzmán \& Moreno 2014). The areas adjacent to the Mazán river are covered by both primary and mature secondary forests, with an important arboreal stratum represented by species such as "Arrayan" (Myrcianthes rhopaloides), "Romerillo" (Prumnopyts montana), "Sarar" (Weimannia fagaroides), "Pururug" (Hedyosmum luteunyii), "Tililin" (Piper andreaum), and "Jigua" (Ocotea sp.), among others. These trees foster the maintenance of a constant humidity and contribute to the absence of a marked dry season, creating a suitable place for the establishment of an important diversity of epiphytic species (Beltrán 2001).

Orchid species description.-Pleurothallis coriacardia Rchb.f. is an abundant species in Mazán Reserve, showing abundant wild populations in primary and secondary forests. Its growth habits are both epiphytic and lithophytic (Fig. 2). The most important morphological characteristics of this species, as recorded in the field include: i) sympodial growth, with unifoliar stalks covered in the base by purple bracts; ii) 


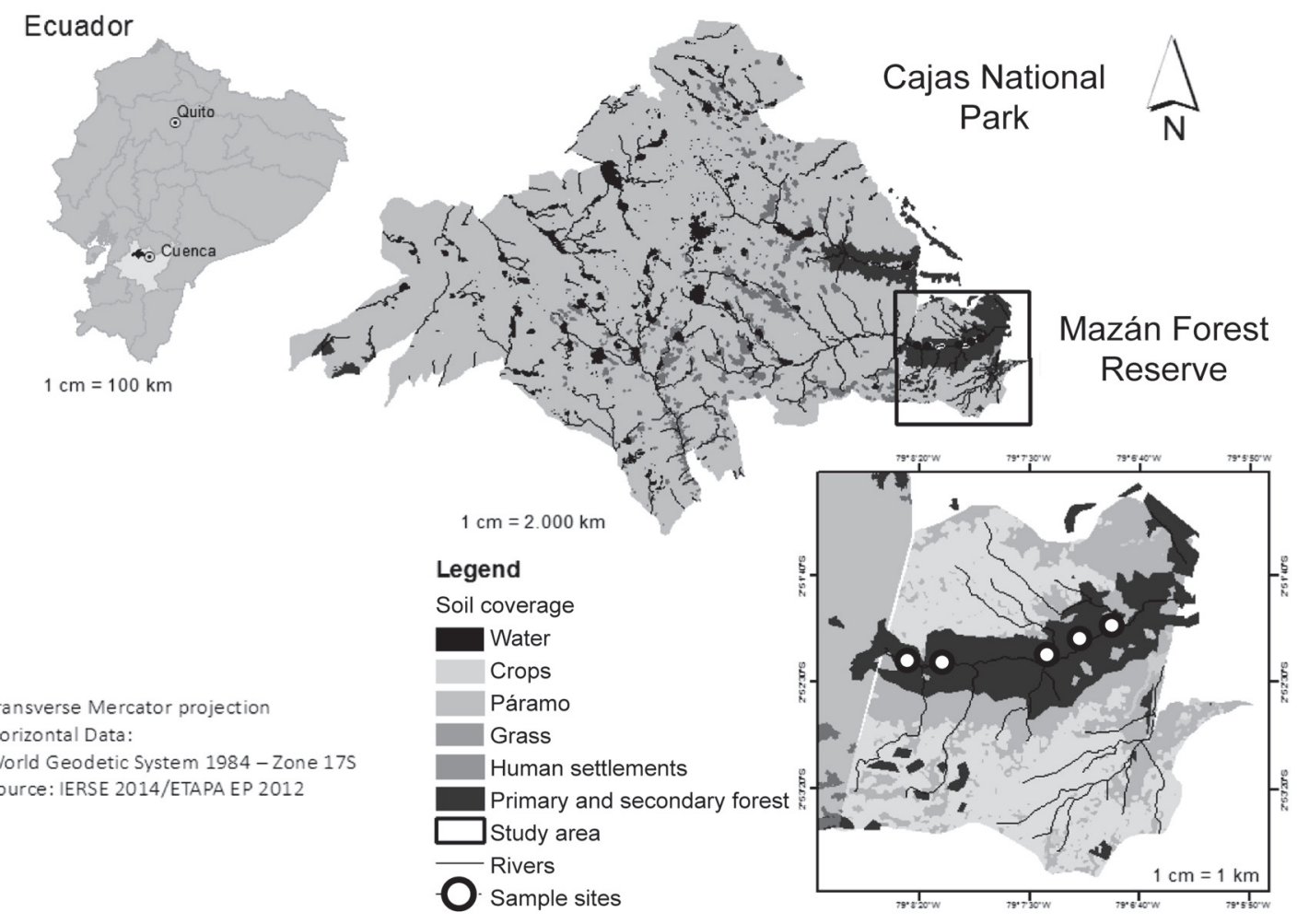

FIgURE 1. Map showing location of the study area in Mazán Forest Reserve, Cajas National Park, Ecuador.

oblanceolate and leathery leaves, sub-petiolated at the base; iii) velamentous roots exhibiting a characteristic green-translucent color at the tip (Fig. 3A); iv) apical inflorescences with up to 5 flowers - exhibiting fused lateral sepals and yellow-colored edges-per stem; v) small and elongated petals, varying from brown/ reddish to yellow; vi) yellow to green lips and columns, with yellow colored pollinia (Fig. 3B); and, vii) apical capsules developing from each flower and containing thousands of pale-yellowish seeds of about $60-40 \mu \mathrm{m}$ in length (Fig. 3C). The presence of asexual propagules emerging from the petiole, showing an abundant development of roots and new stems with no bulbs, was frequently observed (Fig. 3D). We also noticed the presence of numerous $P$. coriacardia protocorms, indicative of natural germination of the orchid seeds. Plant material.- From February to March 2016 root samples were collected from 35 different adult individuals of $P$. coriacardia colonizing either rock substrates, live phorophytes, or decomposing arboreal substrates. Living phorophytes were mainly $M$. rhopaloides, W. fagaroides and Ocotea sp., but also other less representative phorophytes were present. We selected five different sites, separated from each other by no less than $200 \mathrm{~m}$, for collecting samples in the forest (Fig. 1). We took care to include orchids from at least one rock and three of the most representative phorophytes from each site. The samples consisted of several root fragments of approximately $3 \mathrm{~cm}$ in length, which included the green-translucent tips. Each sample was placed inside a sterile plastic bag and transported to the laboratory in Cuenca. Samples were refrigerated at $4^{\circ} \mathrm{C}$ for less than 24 hours after collection until fungal isolations were performed.

Orchid root fragments were surface sterilized following a combination of the procedures of Currah (1987) and Zettler (1997). In brief, root fragments were rinsed with tap water to remove debris, and then submerged for one minute in a solution of $2 \%$ bleach: $70 \%$ ethanol: sterile water $(1: 1: 1)$, followed by several washings with sterile distilled water. Roots were then cut into small pieces $(<1 \mathrm{~mm})$ using a sterile scalpel, 

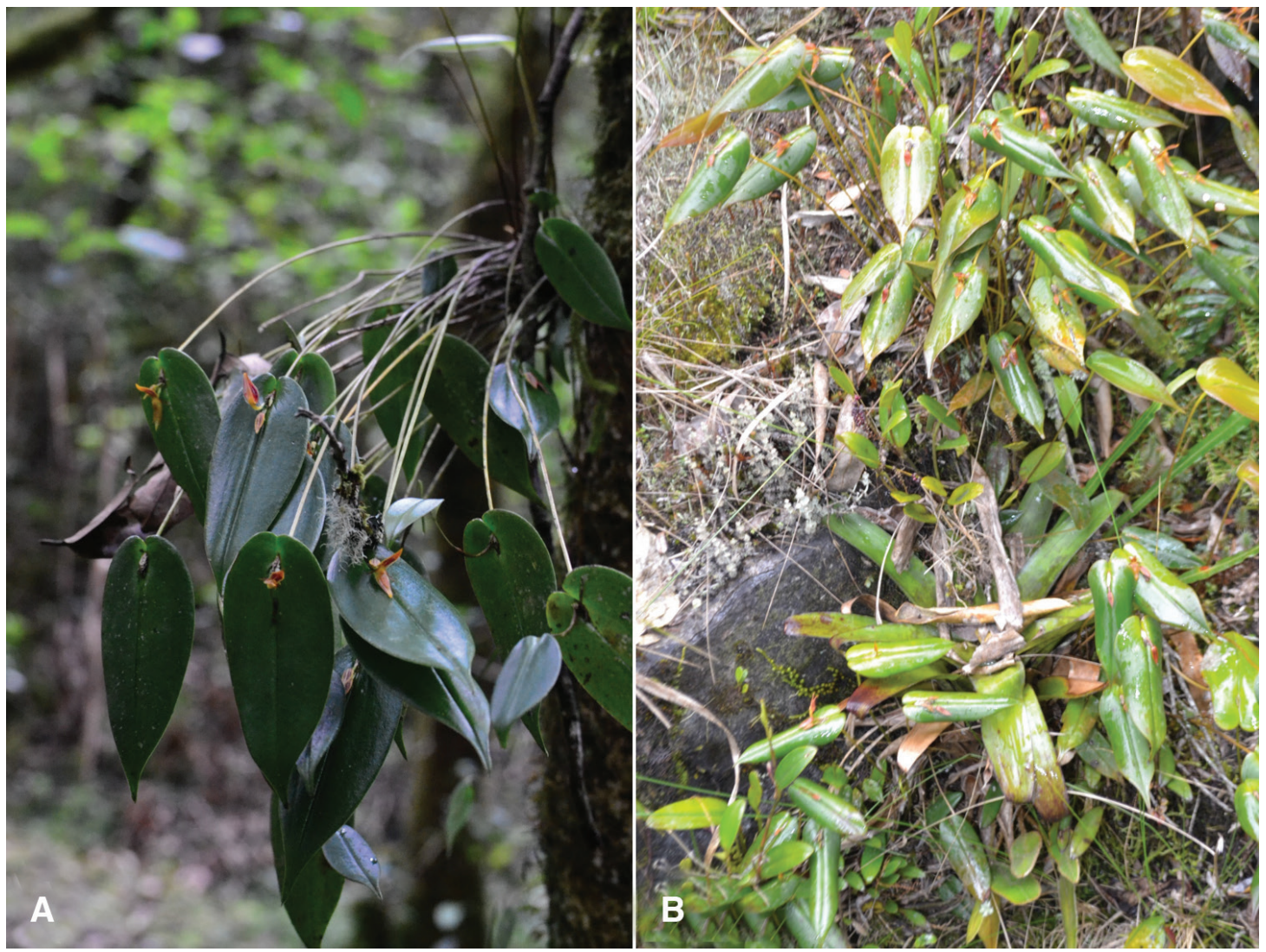

FiguRE 2. Pleurothallis coriacardia growth. Epiphytic (A) and lithophytic (B) habits. Mazán Forest Reserve, Cajas National

Park, Ecuador. Photographs by G. P. Maldonado.

inoculated in molten fungal isolation medium (FIM) (Clements, Muir \& Cribb 1986) that was supplemented with streptomycin $(3 \mu \mathrm{g} \mathrm{mL}-1)$, and incubated at $19^{\circ} \mathrm{C}$. The hyphae that emerged during the next 96 hours were sub-cultured several times in potato dextrose agar (PDA) (Latalova \& Balaz 2010) until their purity was confirmed. The fungal isolates were classified based on their colony morphology, taking into consideration the mycelium color, texture, and pattern of growth. Pure cultures were preserved in oatmeal-agar medium (OMA) at $4^{\circ} \mathrm{C}$ (Zettler 1997).

Seed were harvested from mature, dry capsules of adult $P$. coriacardia individuals in their natural habitat (Mazán Reserve) at the same time that root fragments were collected. Seeds were processed less than 24 hours after collection. For this, the capsules were opened under sterile conditions and seeds were placed in sterile vials (one for each capsule) and stored at $-20^{\circ} \mathrm{C}$ until used (Zettler \& McInnis 1993). Prior to sowing, seeds (of a single capsule) were disinfected using a protocol adapted from Zettler, Delaney \& Sunley (1998). Briefly, seeds were immersed in a solution of $85 \%$ ethanol: $2.5 \%$ bleach: sterile distilled water (1:1:1) for one minute, followed by three successive rinses with sterile distilled water. Seeds were then suspended in $100 \mathrm{~mL}$ of sterile distilled water and transferred from the vial to the germination plates using a sterile syringe within ten minutes for the subsequent sowing in the germination plates, as described in the next section.

\section{Selection of endophytic fungi for symbiotic} germination assays. - In order to reduce the number of fungal isolates for symbiotic germination assays, we conducted a preliminary blind assay to select only those isolates showing a positive effect on the symbiotic germination of $P$. coriacardia seeds. For this, two milliliters of a suspension of disinfected seeds were spread on the surface of OMA plates. Then, in 

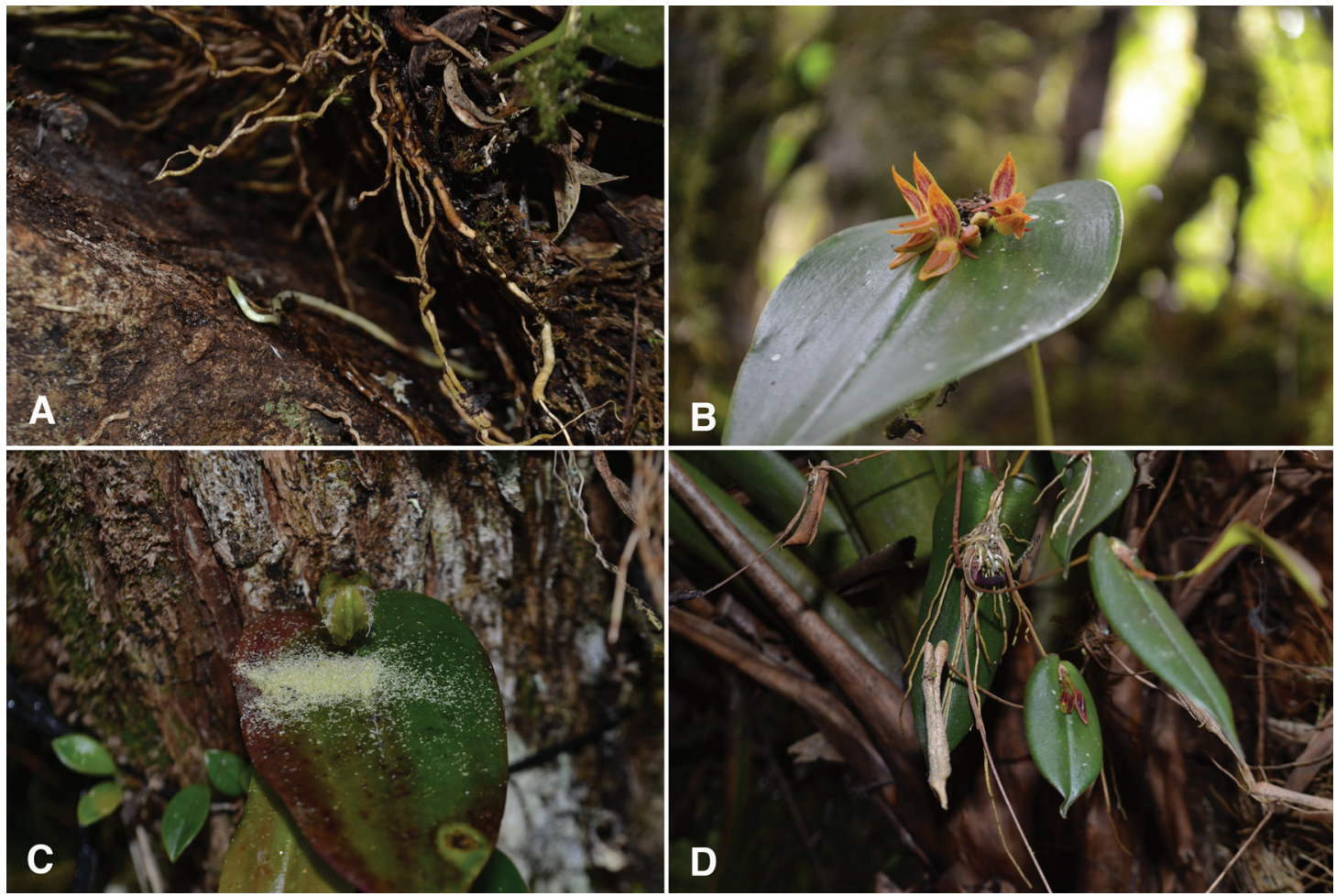

Figure 3. Pleurothallis coriacardia in the Mazán Forest Reserve. A. Roots of adult individual growing on rock substrate.

B. Close-up of an inflorescence. C. Mature seed capsule of an adult individual growing on a phorophytes. D. Close-up of asexual propagules emerging from the stem. Photoghraps by L. A. Yarzábal (A) and G. A. Maldonado (B-D).

the center of each plate one block of agar $\left(\approx 0.5 \mathrm{~cm}^{3}\right)$ containing the mycelium of each fungal strain was inoculated. In total, we tested all 134 isolates twice. Uninoculated OMA plates were used as negative controls for germination. Plates were sealed with Parafilm ${ }^{\mathrm{TM}}$ and incubated in the dark at $19^{\circ} \mathrm{C}$ for two months; then, the plates were exposed to light under a 16/8 h light/dark photoperiod. Approximately ten randomly selected seeds in each plate were visually inspected with a stereo microscope (Olympus SZ61) every two weeks for five months.

The embryo development of each seed was scored according to a modification of the scale from Seaton \& Ramsay (2009) as follows: $0=$ no germination/dead seeds; $1=$ seed with viable embryo; $2=$ swollen embryo; $3=$ testa rupture by enlarged embryo; 4=protocorm development; 5=appearance of first true leaf. The embryo diameters of 10 randomly selected seeds were recorded, per replicate and per treatment.

After obtaining the results of the preliminary symbiotic germination assay, genomic DNA was extracted from fungal isolates sharing the same macroscopic (color, appearance, consistency, size and shape) and microscopic (mycelium, hypha and conidia) characteristics. The 134 isolates were grouped into 76 morphotypes. DNA was extracted for polymerase chain reaction (PCR) amplification following the protocol of Cennis (1992). The ITS1-5.8S-ITS2 region was amplified by PCR using eukaryote universal primers ITS1 and ITS4 (White et al. 1990). The thermal profile was as follows: $94^{\circ} \mathrm{C}$ for $3 \mathrm{~min}$, followed by 35 cycles of $94^{\circ} \mathrm{C}$ for $30 \mathrm{~s}, 57.4^{\circ} \mathrm{C}$ for $45 \mathrm{~s}$ and $72^{\circ} \mathrm{C}$ for $45 \mathrm{~s}$, with a final extension step of $7 \mathrm{~min}$ at $72^{\circ} \mathrm{C}$. The presence of amplicons was verified by agarose gel electrophoresis, using SYBR Safe DNA gel stain (Invitrogen, Carlsbad, CA). The amplicons were sent for further purification and sequencing to an external service provider.

To assign each fungal isolate to a particular taxon, we compared the obtained nucleotide sequences with those deposited in the GenBank database of the National Center for Biotechnology Information (NCBI 2017) and the UNITE fungal 
ITS reference database (Version 7.1) (Kõjalg et al. 2005, Nilsson et al. 2018) using BLAST (Basic Local Alignment Search Tool) (Altschul et al. 1997). Following a strict criteria, we provided genus names only to those isolates whose sequences exhibited an identity $>95 \%$ to the reference sequence and with an $\mathrm{E}$ value lower than or close to 0.001 . Isolates exhibiting lower sequence identities were labelled at the order- or family-level name, or referred to as 'unknown' fungi.

Symbiotic germination assays. - Seeds were surface sterilized as previously described and spread over the surface of OMA. Fifteen selected fungal isolates were then inoculated as described above, and the embryo development was monitored every four weeks for a total period of four months. The test was performed with ten replicates per fungal isolate. For a positive control of germination, seeds treated as previously indicated were spread on the surface of Phytamax ${ }^{\mathrm{TM}}$ Orchid medium P6793 (Sigma-Aldrich) (pH 5.6), supplemented with gibberellic acid including the analysis of three different concentrations: 0,10 and $20 \mu \mathrm{g} \mathrm{mL}^{-1}$ (Sigma Aldrich). This nutrient-rich medium is frequently used for asymbiotic germination of orchid seeds and was expected to provide the necessary nutrients to support germination of $P$. coriacardia seeds. The negative control of germination uninnoculated OMA as described above.

To score the seed development, we followed the same scale used in the preliminary assay, counting all seeds in each plate. To establish a relationship between seed diameter and developmental stage we only considered an average of 30 seeds, and conducted a Kruskal-Wallis non-parametric test and a sequential Bonferroni-corrected test $(p=0.003)$ (Holm 1979). The same analysis was used to test whether there was a difference in the development rates of each stage with the different isolates and with the negative and positive control. Embryo development and seed diameter data were analyzed with XLSTAT (V. 2014.5.03) (Addinsoft 2014).

Results. In total, 134 pure fungal isolates were obtained from $P$. coriacardia roots and as previously stated, they were grouped into 76 morphotypes based on macroscopic and microscopic characteristics. Isolates were identified using BLAST searches.
Coprinellus (Psathyrellaceae) was the most frequently occurring genus in the entire collection $(20 \%$ of the isolates), followed by Fusarium (Nectriaceae), Nigrospora (Trichosphaeriales), and Trichoderma (Hypocreaceae) (represented by 10\%, 10\%, and $8 \%$ of the isolates, respectively). The isolates originated from $P$. coriacardia individuals colonizing various substrates. We found 16 isolates originated from lithophytic plants; 82 from epiphytic individuals colonizing the most representative phorophytes (7 from $W$. fagaroides; 17 from Ocotea sp.; 30 from $M$. rhopaloides; 28 on other less abundant phorophytes); and the remaining 36 originated from $P$. coriacardia collected from decomposing substrates (Fig. 4). Information of the entire endophytic collection are detailed in Appendix 1.

Twenty-three out of 134 fungal isolates exerted a positive effect on $P$. coriacardia embryo development in the preliminary symbiotic germination assay (data not shown). The relationship between embryo diameter and growth stage was established from the results obtained in this assay in order to confirm the suitability of the scale used to determine the stage of development. As can be seen in Fig. 5, there were significant differences between the average embryo diameter of seeds at different developmental stages. Based on these results, we selected 15 fungal strains for the final assay and discarded strains that exhibited a systematic contamination of the growth medium during germination assays.

Isolates selected from this assay were identified as Ilyonectria (6MF3), Coprinellus (18.1MF3, 22MF2.1, 19MF1.4.1, 20MF3, 21MF1, and 22MF2.3), Nigrospora (18.2MF2, 26MF1.4.1), Chaetomium (17MR4), Fusarium (29MF2.8), Trametes (33MF2.2), Trichoderma (3MF5), and Unidentified Endophyte (12.1MF3, 27MF3).

Three of these 15 selected isolates-6MF3, 18.1MF3, and 22MF2.1— significantly promoted embryo development after 12-weeks incubation, as compared to the negative control (Fig. 6). Noticeably, two of these fungal isolates were closely related to Coprinellus species. It is important to highlight that inoculation with eight of these selected isolates allowed the embryos to develop until stage 3, even though the percentages varied from $3 \%$ to $30 \%$ depending on the isolate. 


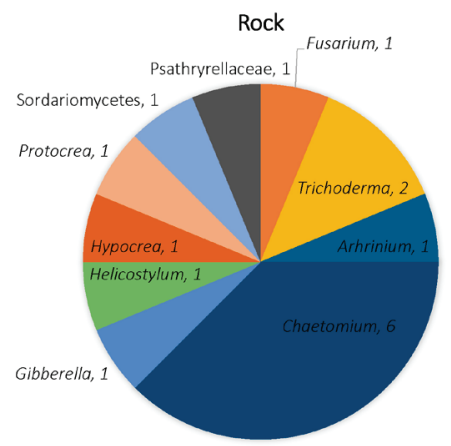

Myrcianthes rhopaloides

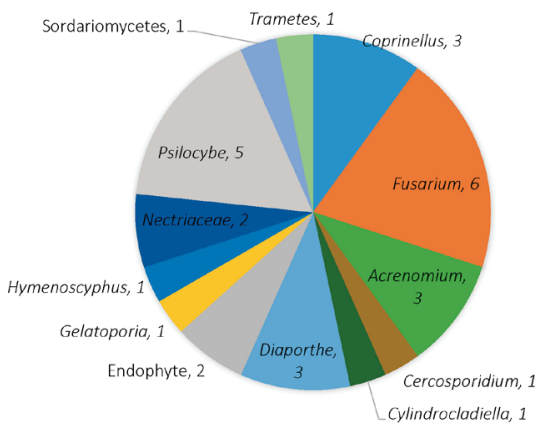

Phorophyte in decomposition

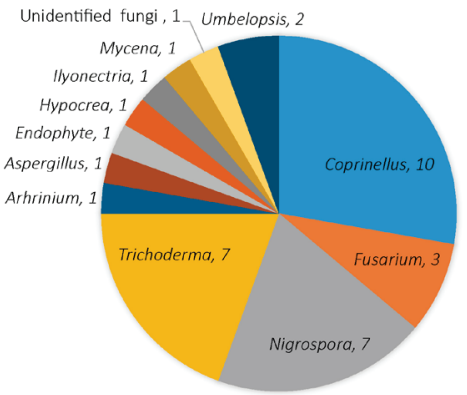

Phorophytes

Ocoteasp.

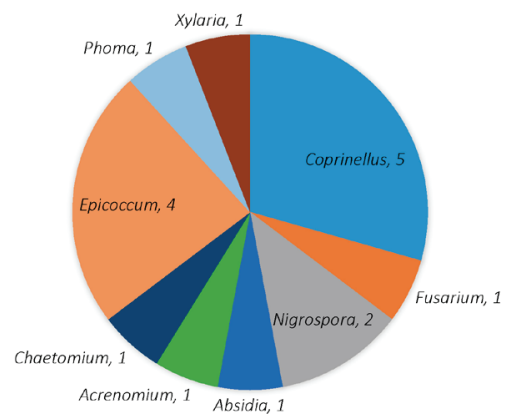

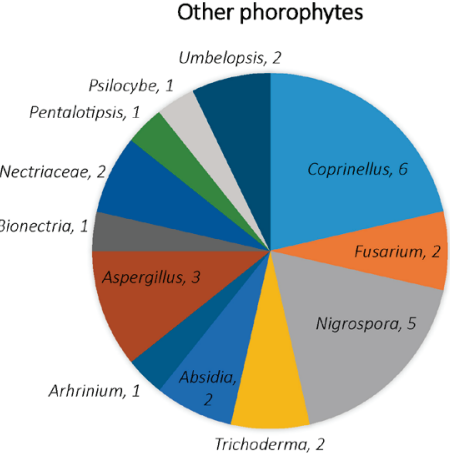

Weinmannia fagaroides

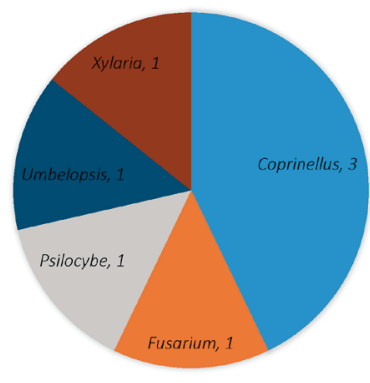

FIGURE 4. Distribution of endophytic fungi. In the upper panel there are three colonization substrates, in the lower panel there are three phorophytes substrates. The labels next to the fungus name represents the number of isolates.

Seeds of $P$. coriacardia sowed in GAsupplemented Phytamax ${ }^{\mathrm{TM}}$ medium (included as a positive control of germination) produced some unexpected results: after 12-weeks incubation, all seeds reached stage 1 (viable embryo) regardless the concentration of GA, but there was no further development after that point. Surprisingly, 3\% of seeds incubated in OMA medium (included as negative control of germination), reached stage 2 (embryo swelling) and then stopped developing. As can be seen in Fig. 5, the average diameter of the embryo was larger in seeds incubated in OMA medium (our negative control), when compared to those incubated in GA-supplemented Phytamax ${ }^{\mathrm{TM}}$ medium ( $p=0.0105)$ (considered as positive control). We considered the experiment for 12 weeks, with a sequential revision of the plates, however, after this time some plates with developing seeds were reviewed but until week 16 we did not find evidence of changes in the development of $P$. coriacardia seeds.
Discussion. Our findings show that the cultivable fraction of endophytic fungi colonizing $P$. coriacardia roots was rich in species irrespective of the substrate type on which the orchids grew. The isolates belonging to the Coprinellus genus were the endophytic partners which are the most frequently associate to $P$. coriacardia roots. Furthermore, some of the isolates, such as those belonging to the Ilyonectria and Coprinellus genera, stimulated seed germination by promoting embryo development in vitro until testa rupture (stage 3). Endophytic fungi colonizing roots of orchids have been reported to have a crucial role in plant propagation, embryo development, seed germination, and protocorm nutrition (Rasmussen et al. 2015, Ma et al. 2015, Pant et al. 2017). For instance, Tolumnia variegata in the presence of Ceratobasidium have a positive influence in seed germination (Otero et al. 2005), Epulorhiza spp. promoted protocorm development until leaf production of Cyrtopodium glutiniferum (Pereira et al. 2015). Besides, Fusarium spp. have 


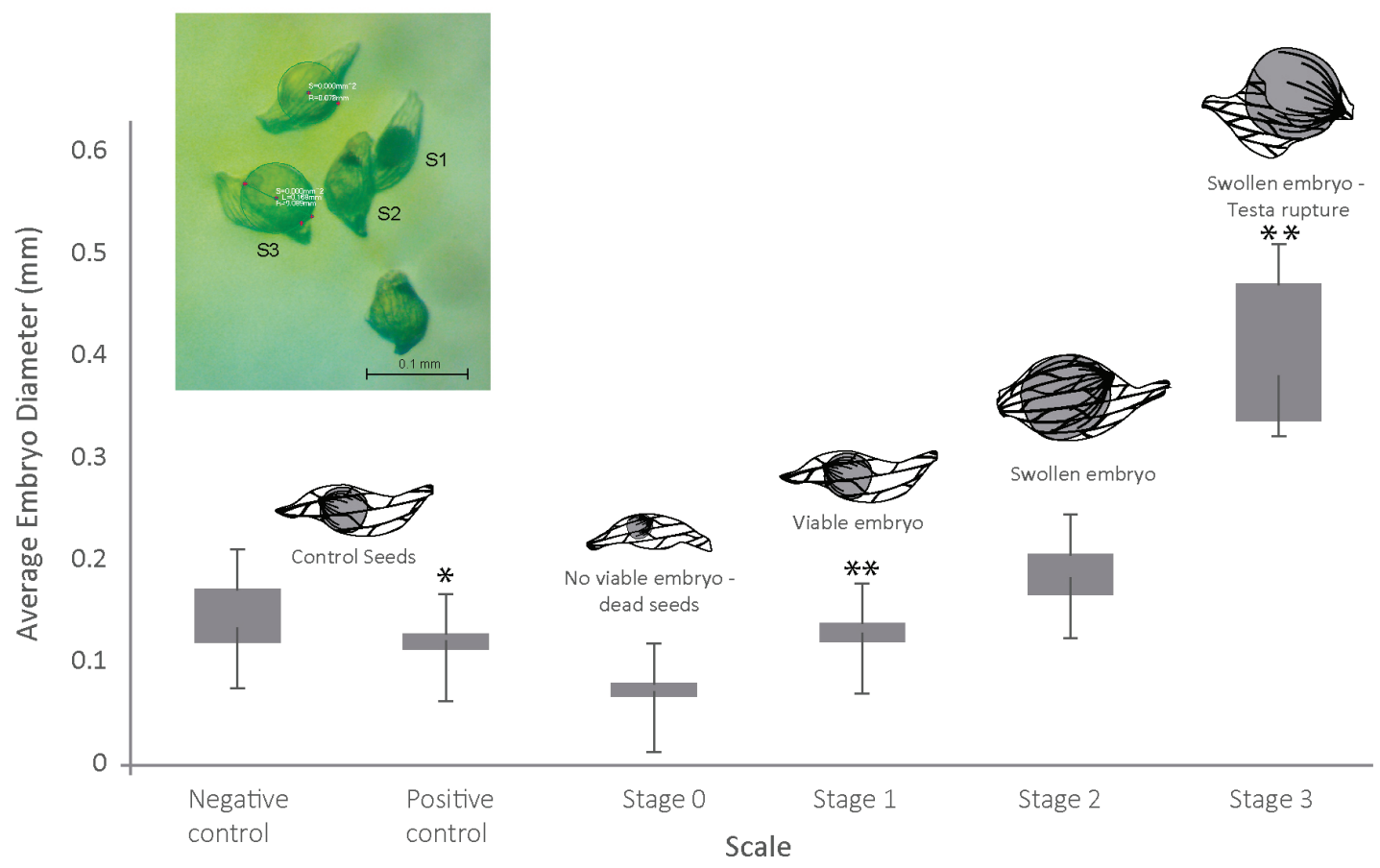

FiguRE 5. Diameter versus embryo developmental stage of $P$. coriacardia seeds. The schemes illustrate the morphology of the seeds at different stages. Inset: the picture shows seeds at different developmental stages, as seen under a stereo microscope, S1 represents Stage 1=Viable embryo; S2, Stage 2=swollen embryo; S3, Stage 3=Testa rupture. Average diameter identified with asterisks differ significantly from the negative control $p<0.001$; the two asterisks is $p<0.01$.

been described as active auxin- and gibberellic acid producers in Dendrobium sp., Pterostylis sp. and Cymbidium sp., promoting high germination rates and playing important roles in the development of protocorms (Tsavkelova et al. 2008).

The root fungal endophytic communities of $P$. coriacardia and other green orchids in Andean ecosystems have been poorly studied. Greater research efforts have been made using massive sequencing techniques for understanding the mycorrhizal and endophytic fungi associated with green epiphytic Andean orchids like Odontoglosum pardinum, Epidendrum marsupial, Cyrtochilum pardinum, C. flexuosum, C. myanthum and Maxillaria calantha reported for the same study site (Cevallos et al. 2018, Guzmán \& Moreno 2014, Herrera et al. 2018, Herrera et al. 2019). However, no information is available regarding the cultivable fraction of fungi for these species. We show high incidence of root endophytic fungi in adult plants of $P$. coriacardia from Mazán Reserve. We found that the orchids growing on live phorophytes-W. fagaroides, Ocotea sp., and M. rhopaloides - and over decomposing arboreal substrates were similarly colonized by fungi customarily defined as saprophytes and pathogens such as Coprinellus, Nigrospora, Trichoderma, and Fusarium. In contrast, orchids growing on rock substrate had a different composition in which we identified morphotypes closely related to Fusarium tricintum and Helicostylum, in addition to observing a greater abundance in individuals of the genus Chaetomium whereas fungal isolates closely related to Coprinellus were completely absent.

The fact that a fungus can be isolated from a section of root tissue does not mean it is mycorrhizal. Nonmycorrhizal endophytes, saprophytes, and pathogens are commonly reported in orchid roots (Bayman \& Otero 2006, Bayman et al. 2016, Selosse et al. 2010) and members of this guild have shown positive roles in orchid development from seed germination to vegetative growth. The first non-Rhizoctonia-like genera reported to show a symbiotic role was Fusarium 


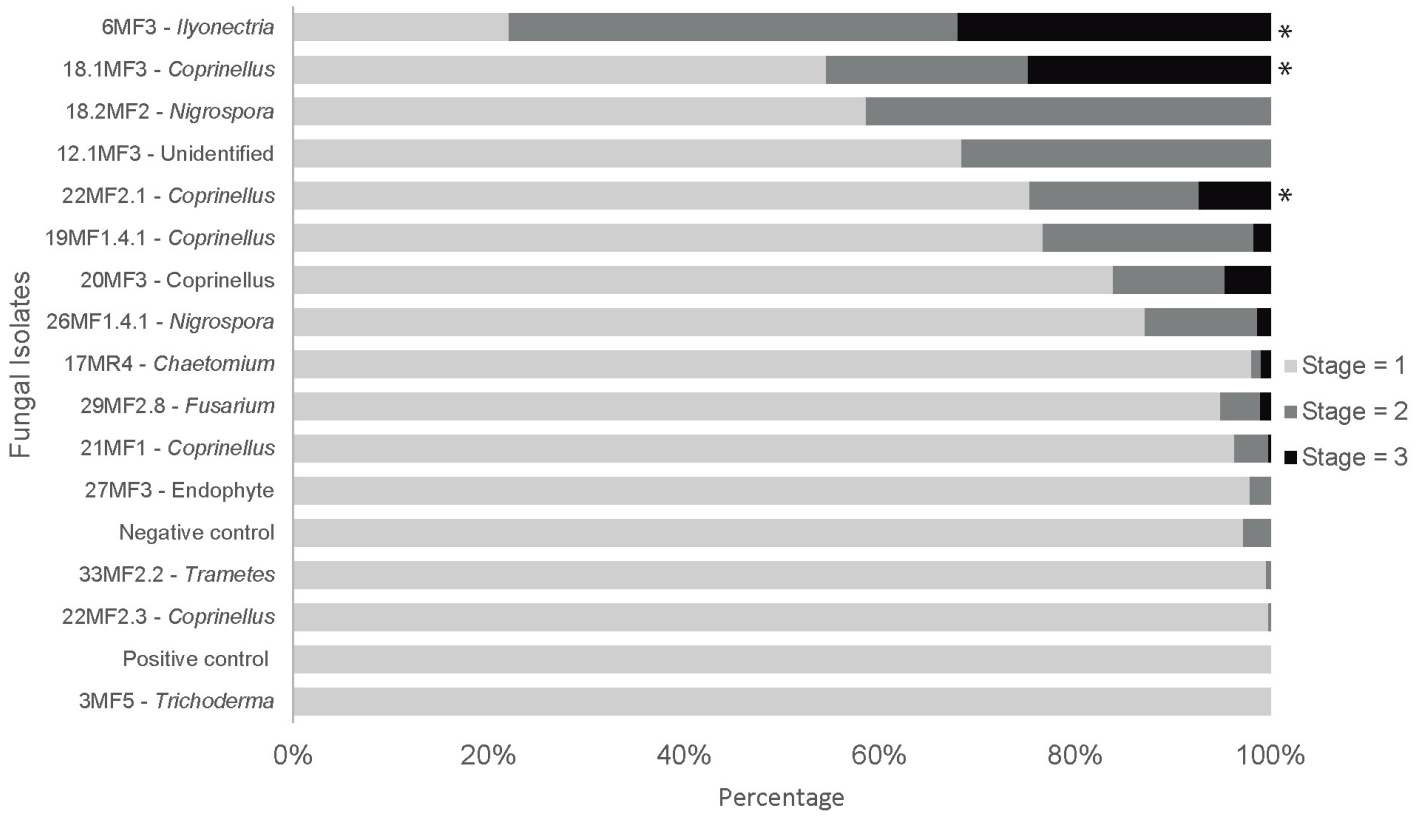

Figure 6. Percentage of $P$. coriacardia seeds that reached stage 1, 2 and 3 by week 12 of symbiotic germination in the presence of each fungal isolate. The percentage in each stage was calculated by dividing the number of seeds in each stage by the total number of viable seeds in each sample. The positive and negative controls of germination are also included. Treatments identified with asterisks differ significantly from the negative control $p<0.001$.

in the orchid Cypripedium reginae (Vujanovic 2000), with significance in seed germination. The known saprophytic fungi Mycena, Trichoderma, and Chaetomium have also been reported to play a specific role in orchid development (Pant et al. 2017); all of these genera have been reported in this study.

The genus Coprinellus, also saprophytic fungi, was first described as very frequently associated with the terrestrial orchid Epipogium roseum by Yamato et al. (2005), they suggest the existence of a highly specific relationship between this orchid species and members of the Psathyrellaceae family, owing to the high abundance of pelotons observed in their roots. Yagame et al. (2013) confirmed the mycorrhizal status of Coprinellus by symbiotic cultivation of seeds from Cremastra appendiculata, a photosynthetic terrestrial orchid, and confirmed the presence and mycorrhiza formation by Coprinellus in Cremastra aphylla (Yagame et al. 2018). Isolates belonging to this genus were detected very frequently in our study, a result which also confirm previous findings by Salazar et al. (2020). We also showed Coprinellus's important role as a promotor of germination for this species, with two out of five tested isolates leading seeds to stage 3 (testa rupture) of development.

Previous studies about the germination of seeds from Pleurothallis orchids and symbiotic fungal associations are scarce. The only precedent to the present work is in relation to achievement for seed development of Pleurothallis truncata up to stage 4 after a 10-week incubation (León \& Molina 2015) in Murashige \& Skoog medium, supplemented with coconut water. Incidentally, the authors pointed out that attempts to achieve symbiotic germination of $P$. truncata seeds with the help of Rhizoctonialike isolates were unsuccessful. On the contrary, we avoided the bias of selecting Rhizoctonia-like features through a preliminary blind germination assay, which probably lead to the unexpected discovery of an additional genus, Ilyonectria, that promoted embryo development of $P$. coriacadia.

Members of the Ilyonectra genus and their allied anamorphic taxa are often detected when studying rhizospheric communities of plants like Pyrola sp., Populus sp., Enkianthus sp., and Alnus sp. among others (Geml et al. 2014, Obase \& Marsuda 2014, 
Unterseher, Per \& Schnittler 2013). Even though there is not much information concerning the ecological role those fungi might play, recent findings support their functioning as promoters of germination of certain woody plant species (Bonito et al. 2014). The results presented here showing the promotion of $P$. coriacardia germination by Ilyonectria sp. strain 6M3 are in line with that hypothesis.

One particular result that deserves to be considered with caution was the slow rate of embryo development of $P$. coriacardia seeds in a GA-supplemented medium rich in simple sugars (Phytamax ${ }^{\mathrm{TM}}$ ). This is a widely used medium for in vitro asymbiotic germination of seeds from many orchid species, which was the reason we included it as a positive control of germination for our experiments. However, our results suggest that either Phytamax ${ }^{\mathrm{TM}}$ is not well suited for P. coriacardia germination in vitro, or the germination of this species is particularly slow. We believe that the nutrient richness of this medium may be inhibitory to germination of $P$. coriacardia seeds, as previously demonstrated with other orchid species (Rafter et al. 2016). We are cautious to suggest a highly specialized relationship with $P$. coriacardia, despite our results, because we only isolated fungi from adult plants, and as it has been reported, mature plants are not implicated in the symbiotic germination of orchids seeds (Ovando et al. 2005). Besides, for epiphytic tropical orchids a low specificity condition between orchids and the fungal guests have been well documented in comparison to their terrestrial relatives (Jacquemyn et al. 2010, Johnson et al. 2007, Stewart \& Kane 2006). We consider that the isolation of fungi from natural seedlings, probably using seed baiting techniques (Rasmussen \& Whigham 1993), are necessary to confirm this association. It is important to point out that in the field it was common to observe protocorms and seedlings from epiphytic orchids, near to adult populations of $P$. coriacardia, located mostly in rock substrates, where we did not register Coprinellus genus.

After the 16-week analysis, no further development of $P$. coriacardia seeds was observed, which may be explained by various hypotheses. Halted seed development may be due to the necessity of another nutrient source not provided by the fungal endophytes (Zettler pers. comm. 2017). Another hypothesis is that fungal presence improved access to water (Ovando et al. 2005), considering the results of the negative controls, or that the fungi were used as an initial carbon source. Accordingly, the developing seed digested the fungi until it reached a large enough size to cause the testa to rupture, but after this point other obligate symbionts may be needed for establishment of the protocorm, and/ or possibly the fungi stopped acting as providers and became pathogenic, as in the case of Ilyonectria.

We hope our results could aid in improving descriptions of the ecology of Andean orchids and their endophytes and to support propagation programs of $P$. coriacadia both for conservation and commercial purposes which could in turn help reduce extraction from their natural habitats.

ACKNOWLEDGMENTS. This project was funded by internal competitive funds from the University of Cuenca through project "Establecimiento de un banco de germoplasma de orquídeas nativas del sur del Ecuador y hongos micorrízicos asociados a ellas" under research permits 093-16-ICFUNGI-DPAA/MA; 121-2016-DPAA/MA and Genetic Resource Access contract MAE-DNB-CM-2018-0084 granted by the National Biodiversity Direction of the Ecuadorian Ministry of the Environment. We express our sincere gratitude to Jazmín Salazar, Paulina Villena and Antonio Vallecillo, for their constant advice and assistance. Thanks are also extended to Gabriela Maridueña and Adela Quevedo from CIBE - ESPOL (Guayaquil) and to Anne T. Pollard from the University of Idaho. Finally, we acknowledge VLIR Network Postgraduate Program.

\section{LITERATURE CITED}

Addinsoft. (2014). XLSTAT (Version 2014.5.03) [Software]. Retrieved from http://www.xlstat.com [Accessed on November 18, 2019].

Altschul, S., Madden, T., Shaffer, A., Zhang, J., Zhag, Z., Miller, W. \& Lipman, D. (1997). Gapped BLAST and PSI BLAST: a new generation of protein database research programs. Nucleic Acids Research, 25(17), 3389-3402. DOI: https://doi.org/10.1093/nar/25.17.3389

Bayman, P. \& Otero, J. T. (2006). Microbial endophytes of orchid roots. In: B. Schulz, C. Boyle \& T. N. Sieber (Eds.), Soil Biology (pp. 153-177). Berlin Heidelberg: Springer. 
Bayman, P., Mosquera-Espinosa, A. T., Saladini-Aponte, C. M., Hurtado-Guevara, N. C. \& Viera-Ruiz, N. L. (2016). Age-dependent mycorrhizal specificity in an invasive orchid, Oeceoclades maculata. American Journal of Botany, 103(11), 1880-1889.

Beltrán, J. B. (2001). Composición florística, estructura y dinámica del Bosque Primario en Mazán, Cuenca, Ecuador. Dissertation, University of Azuay. Cuenca-Ecuador.

Bonfante, P. \& Anca, I. A. (2009). Plants, mycorrhizal fungi, and bacteria: a network of interactions. Annual Review of Microbiology, 63, 363-383. DOI: https://doi.org/10.1146/annurev.micro.091208.073504

Bonito, G., Reynolds, H., Robeson II, M. S., Nelson, J., Hodkinson, B. P., Tuskan, G., Schadt, C. W. \& Vilgalys, R. (2014). Plant host and soil origin influence fungal and bacterial assemblages in the roots of woody plants. Molecular Ecology, 23, 3356-3370. DOI: https://doi.org/10.1111/mec.12821

Borba, E., Semir, J. \& Shepherd, G. (2001). Self-incompatibility, inbreeding depression and crossing potential in five Brazilian Pleurothallis (Orchidaceae) species. Annals of Botany, 88, 89-99. DOI: https://doi.org/10.1006/anbo.2001.1435

CaraDona, P. \& Ackerman, J. (2012). Reproductive assurance for a rewardless epiphytic orchid in Puerto Rico: Pleurothallis ruscifolia (Orchidaceae, Pleurothallidinae). Caribbean Journal of Science, 46(2-3), 249-257. DOI: https://doi. org/10.18475/cjos.v46i2.a13

Cennis, J. L. (1992). Rapid extraction of fungal DNA for PCR amplification. Nucleic Acids Research, 20(9), 2380.

Cevallos, S., Herrera, P., Sánchez-Rodríguez, A., Declerck, S. \& Suárez, J. P. (2018). Untangling factors that drive community composition of root associated fungal endophytes of Neotropical epiphytic orchids. Fungal Ecology, 34, $67-75$.

CITES. (2002). Appendices I, II and III. Convention on International Trade in Endangered Species of Wild Fauna and Flora. Retrieved from http://www.cites.org/esp/app/index.php [Accessed on November 15, 2019].

Clements, M. A., Muir, H. \& Cribb, P. J. (1986). A preliminary report on the symbiotic germination of European terrestrial orchids. Kew Bulletin, 41, 437-445.

Currah, R. S. (1987) Thanatephorus pennatus sp. nov. isolated from mycorrhizal roots of Calypso bulbosa (Orchidaceae) from Alberta. Canadian Journal of Botany, 65(9), 1957-1960. DOI: https://doi.org/10.1139/b87-268

De Bary, A. (1879). Die Erscheinung der Symbiose. In: K. J. Trubner (Ed.), Vortrag auf der Versammlung der Naturforscher und Ärtze zu Cassel (pp. 1-30). Strassburg, Germany: Verlag.

Geml, J., Pastor, N., Fernández, L., Pacheco, S., Semenova, T. A., Becerra, A. G. \& Nouhra, E. R. (2014). Large-scale fungal diversity assessment in the Andean Yungas forests reveals strong community turnover among forest types along an altitudinal gradient. Molecular Ecology, 23(10), 2452-2472. DOI: https://doi.org/10.1111/mec.12765

Guzmán, N. \& Moreno, B. J. (2014). Efecto de la altitud en la composición y riqueza de hongos micorrízicos de orquídeas epífitas en bosques montano altos del Sur del Ecuador. Dissertation, University of Azuay, Cuenca-Ecuador.

Herrera, P., Kottke, I., Molina, M. C., Méndez, M. \& Suárez, J. P. (2018). Generalism in the interaction of Tulasnellaceae mycobionts with orchids characterizes a biodiversity hotspot in the tropical Andes of Southern Ecuador. Mycoscience, 59(1), 38-48.

Herrera, P., Suárez, J. P., Sánchez-Rodríguez, A., Molina, M. C., Prieto, M. \& Méndez, M. (2019). Many broadly-shared mycobionts characterize mycorrhizal interactions of two coexisting epiphytic orchids in a high elevation tropical forest. Fungal Ecology, 39, 26-36.

Holm, S. (1979). A simple sequentially rejective multiple test procedure. Scandinavian Journal of Statistics, 6(2), 65-70.

Jacquemyn, H., Honnay, O., Cammue, B., Brys, R., Lievens, B. (2010). Low specificity and nested subset structure characterize mycorrhizal associations in five closely related species of the genus Orchis. Molecular Ecology, 19(18), 4086-4095. DOI: https://doi.org/10.1111/j.1365-294X.2010.04785.x

Jiménez, M. (2014). Orquídeas del Ecuador-Número de especies, endemismo, especies amenazadas y su manejo adecuado. Actualidad, 1-3.

Johnson, T. R., Stewart, S. L., Dutra, D., Kane, M. E. \& Richardson, L. (2007). Asymbiotic and symbiotic seed germination of Eulophia alta (Orchidaceae) - preliminary evidence for the symbiotic culture advantage. Plant Cell, Tissue and Organ Culture, 90(3), 313-323.

Kõjalg, U., Larsson, K-H, Abarenkov, K., Nilsson, R. H., Alexander, I. J., Eberhardt, U., Erland, S., Høiland, K., Kjøller, R., Larsson, E., Pennanen, T., Sen, R., Taylor, A. F. S., Tedersoo, L., Vrålstad, T. \& Ursing, B.M. (2005). UNITE: a database providing web-based methods for the molecular identification of ectomycorrhizal fungi. New Phytologist, 166, 1063-1068.

Kottke, I., Setaro, S., Haug, I., Herrera, P., Cruz, D., Fries, A., Gawlik, J., Homeier, J., Werner, F., Gerique, A. \& Suárez, J. P. (2013). Mycorrhiza networks promote biodiversity and stabilize the tropical mountain rain forest ecosystem: 
perspectives for understanding complex communities. In: J. Bendix, E. Beck, A. Bräuning, F. Makeschin, R. Mosandl, S. Scheu \& W. Wilcke (Eds.), Ecosystem services, biodiversity and environmental change in a tropical mountain ecosystem of south Ecuador (Vol. 221) (pp. 187-203). Berlin Heidelberg: Springer-Verlag. DOI: https://doi. org/10.1007/978-3-642-38137-9

Laforest-Lapointe, I., Paquette, A., Messier, C. \& Kembel, S. W. (2017). Leaf bacterial diversity mediates plant diversity and ecosystem function relationships. Nature, 546(7656), 145-147. DOI: https://doi.org/10.1038/nature22399

Latalova, K. \& Balaz, M. (2010). Carbon nutrition of mature green orchid Serapias strictiflora and its mycorrhizal fungus Epulorhiza sp. Biologia Plantarum, 54(1), 97-104. DOI: https://doi.org/10.1007/s10535-010-0014-2

León, T. \& Molina, R. (2015). Aislamiento y selección de micorrizas con evaluación preliminar de su efecto en la germinación de orquídeas en el orquideario de la Universidad de Cuenca. Dissertation, University of Cuenca, Cuenca-Ecuador.

Ma, X., Kang, J., Nontachaiyapoom, S., Wen, T. \& Hyde, K. D. (2015). Non-mycorrhizal endophytic fungi from orchids. Current Science, 108, 1-16.

Murashige, T. \& Skoog, F. (1962). A revised medium for rapid growth and bio assays with tobacco tissue cultures. Physiologia Plantarum, 15(3), 473-497.

NCBI (National Center for Biotechnology Information). (2017). GenBank Databases. National Library of Medicine, U.S.A. Retrieved from https://www.ncbi.nlm.nih.gov/ [Accessed on December 1, 2019].

Nilsson, R. H., Larsson, K.-H., Taylor, A. F. S., Bengtsson-Palme, J., Jeppesen, T. S., Schigel, D., Kennedy, P., Picard, K., Glöckner, F. O., Tedersoo, L., Saar, I., Kõljalg, U. \& Abarenkov, K. (2018). The UNITE database for molecular identification of fungi: handling dark taxa and parallel taxonomic classifications. Nucleic Acids Research, 47(D1), D259-D264. DOI: https://doi.org/10.1093/nar/gky1022

Obase, K. \& Matsuda, Y. (2014). Culturable fungal endophytes in roots of Enkianthus campanulatus (Ericaceae). Mycorrhiza, 24(8), 635-44. DOI: https://doi.org/10.1007/s00572-014-0584-5

Otero, J. T., Bayman, P., \& Ackerman, J. D. (2005). Variation in mycorrhizal performance in the epiphytic orchid Tolumnia variegata in vitro: the potential for natural selection. Evolutionary Ecology, 19(1), 29-43.

Otero, J. T., Ackerman, J. D. \& Bayman, P. (2002). Diversity and host specificity of endophytic Rhizoctonia-like fungi from tropical orchids. American Journal of Botany, 89(11), 1852-1858. DOI: http://doi.org/10.3732/ajb.89.11.1852

Ovando, I., Damon, A., Bello, R., Ambrosio, D., Albores, V., Adriano, L. \& Salvador, M. (2005). Isolation of endophytic fungi and their mycorrhizal potential for the tropical epiphytic orchids Cattleya skinneri, C. aurantiaca and Brassavola nodosa. Asian Journal of Plant Sciences, 4(3), 309-315.

Pant, B., Shah, S., Shrestha, R., Pandey, S. \& Joshi, P. R. (2017). An overview on orchid endophytes. In: A. Varma, R. Prasad \& N. Tuteja (Eds.), Mycorrhiza-nutrient Uptake, Biocontrol, Ecorestoration (pp. 503-524). Cham: Springer.

Pereira, M. C., Rocha, D. I., Veloso, T. G. R., Pereira, O. L., Francino, D. M. T., Meira, R. M. S. A., \& Kasuya, M. C. M. (2015). Characterization of seed germination and protocorm development of Cyrtopodium glutiniferum (Orchidaceae) promoted by mycorrhizal fungi Epulorhiza spp. Acta Botanica Brasilica, 29(4), 567-574.

Rafter, M., Yokoya, K., Schofield, E. J., Zettler, L. \& Sarasan, V. (2016). Non-specific symbiotic germination of Cynorkis purpurea. Mycorrhiza, 26(6), 541-552. DOI: https://doi.org/10.1007/s00572-016-0691-6

Rasmussen, H. N., Dixon, K. W., Jersáková, J., \& Těšitelová, T. (2015). Germination and seedling establishment in orchids: a complex of requirements. Annals of Botany, 116(3), 391-402.

Rasmussen, H. N., \& Whigham, D. F. (1993). Seed ecology of dust seeds in situ: a new study technique and its application in terrestrial orchids. American Journal of Botany, 80(12), 1374-1378.

Riofrío, M. L., Cruz, D., Torres, E., de La Cruz, M., Iriondo, J. M. \& Suárez, J. P. (2013). Mycorrhizal preferences and fine spatial structure of the epiphytic orchid Epidendrum rhopalostele. American Journal of Botany, 100(12), 2339-2348. DOI: http://doi.org/10.3732/ajb.1300069

Salazar, J. M., Pomavilla, M., Pollard, A. T., Chica, E. J., \& Peña, D. F. (2020). Endophytic fungi associated with roots of epiphytic orchids in two Andean forests in Southern Ecuador and their role in germination. Lankesteriana, 20(1), 37-47.

Seaton, P. \& Ramsay, M. (2009). Cultivo de orquídeas por semillas. Richmond, UK: Kew.

Selosse, M. A., Martos, F., Perry, B. A., Padamsee, M., Roy, M. \& Pailler, T. (2010). Saprotrophic fungal symbionts in tropical achlorophyllous orchids: finding treasures among the 'molecular scraps'? Plant Signaling \& Behavior, 5, $349-353$.

Sharma, J., Zettler, L., Van Sambeek, J., Ellersieck, M. \& Starbuck, C. (2002). Symbiotic seed germination and mycorrhizas of federally threatened Platanthera praeclara (Orchidaceae). American Midland Naturalist, 149, 104-120.

Stewart, S. L. \& Kane, M. E. (2007). Symbiotic seed germination and evidence for in vitro mycobiont specificity in Spiranthes 
brevilabris (Orchidaceae) and its implications for species-level conservation. In Vitro Cellular \& Developmental Biology-Plant, 43(3), 178-186.

Suárez, J. P. \& Kottke, I. (2016). Main fungal partners and different levels of specificity of orchid mycorrhizae in the tropical mountain forests of Ecuador. Lankesteriana, 16(2), 299-305. DOI: http://dx.doi.org/10.15517/lank.v16i2.26014

Suárez, J. P., Weiß, M., Abele, A., Garnica, S., Oberwinkler, F. \& Kottke, I. (2006). Diverse tulasnelloid fungi form mycorrhizas with epiphytic orchids in an Andean cloud forest. Mycological Research, 110(11), 1257-1270. DOI: https://doi.org/10.1016/j.mycres.2006.08.004

Suárez, J. P., Weiß, M., Abele, A., Oberwinkler, F. \& Kottke, I. (2008). Members of Sebacinales subgroup B form mycorrhizae with epiphytic orchids in a neotropical mountain rain forest. Mycological Progress, 7(2), 75. DOI: https:// doi.org/10.1007/s11557-008-0554-4

Sun, X. \& Guo, L. (2012). Endophytic fungal diversity: review of traditional and molecular techniques. Mycology, 3(1), 65-76. DOI: https://doi.org/10.1080/21501203.2012.656724

Tao, G., Liu, Z., Hyde, K., Lui, X. \& Yu, Z. (2008). Whole rDNA analysis reveals novel and endophytic fungi in Bletilla ochracea (Orchideaceae). Fungal Diversity, 33, 101-122.

Teixeira da Silva, J. A., Tsavkelova, E. A., Zeng, S., Ng, T. B., Parthibhan, S., Dobránszki, J., Cardoso, J. C. \& Rao, M. V. (2016). Symbiotic in vitro seed propagation of Dendrobium: fungal and bacterial partners and their influence on plant growth and bacterial partners and their influence on plant growth. Planta, 242(1), 1-22. DOI: https://doi.org/10.1007/ s00425-015-2301-9

Tsavkelova, E. A., Bomke, C., Netrusov, A. I., Weiner, J. \& Tudzynski, B. (2008). Production of gibberellic acids by an orchid-associated Fusarium proliferatum strain. Fungal Genetics and Biology, 45, 1393-1403. DOI: https://doi. org/10.1016/j.fgb.2008.07.011

Unterseher, M., Per, D. \& Schnittler, M. (2013). Leaf-inhabiting endophytic fungi of European Beech (Fagus sylvatica L.) co-occur in leaf litter but are rare on decaying wood of the same host. Fungal Diversity, 60, 43-54. DOI: https://doi. org/10.1007/s13225-013-0222-0

Vujanovic, V., St-Arnaud, M., Barabé, D. \& Thibeault, G. (2000). Viability testing of orchid seed and the promotion of colouration and germination. Annals of Botany, 86(1), 79-86.

White, T. J., Bruns, T., Lee, S. J. W. T. \& Taylor, J. W. (1990). Amplification and direct sequencing of fungal ribosomal RNA genes for phylogenetics. In: M. A. Innis, D. H. Gelfand, J. J. Sninsky \& T. J. White (Eds.), PCR Protocols: A guide to methods and applications (pp. 315-322). New York: Academic Press, Inc.

Yagame, T., Funabiki, E., Nagasawa, E., Fukiharu, T. \& Iwase, K. (2013). Identification and symbiotic ability of Psathyrellaceae fungi isolated from a photosynthetic orchid, Cremastra appendiculata (Orchidaceae). American Journal of Botany, 100(9), 1823-1830. DOI: https://doi.org/10.3732/ajb.1300099

Yagame, T., Funabiki, E., Yukawa, T. \& Nagasawa, E. (2018). Identification of mycobionts in an achlorophyllous orchid, Cremastra aphylla (Orchidaceae), based on molecular analysis and basidioma morphology. Mycoscience, 59(1), 18-23.

Yamato, M., Yagame, T., Suzuki, A. \& Iwase, K. (2005). Isolation and identification of mycorrhizal fungi associating with an achlorophyllous plant, Epipogium roseum (Orchidaceae). Mycoscience, 46, 73-77. DOI: https://doi.org/10.1007/ s10267-004-0218-4

Yoder, J., Zettler, L. \& Stewart, S. (2000). Water requirements of terrestrial and epiphytic orchid seeds and seedlings, and evidence for water uptake by means of mycotrophy. Plant Science, 156, 145-150. DOI: https://doi.org/10.1016/S01689452(00)00246-6

Zettler, L. (1997). Terrestrial orchid conservation by symbiotic seed germination: Techniques and perspectives. Selbyana, 18(2), 188-194.

Zettler, L., Delaney, T. \& Sunley, J. (1998). Seed propagation of the epiphytic green fly orchid, Epidendrum conopseum R. Brown, using its endophytic fungus. Selbyana, 19(2), 249-253.

Zettler, L. \& McInnis, T. (1993). Symbiotic seed germination and development of Spiranthes cernua and Goodyera pubescens (Orchidaceae: Spiranthoideae). Lindleyana, 8(3), 155-162.

Zettler, L., Sharma, J. \& Rasmussen, F. P. N. (2003). Mycorrhizal diversity. In: K. Dixon, S. P. Kell, R. L. Barrett \& P. J. Cribb (Eds.), Orchid conservation (pp. 205-226). Kota Kinabalu, Sabah, Borneo: Natural History Publications. 
APPENDIX 1. Molecular identification of endophytic fungi isolated from $P$. coriacardia roots samples in the Mazán Forest

Reserve (Azuay Province, Ecuador) based on the closest match in the GenBank database.

\begin{tabular}{|c|c|c|c|c|c|c|c|}
\hline \multirow{2}{*}{\multicolumn{2}{|c|}{ Isolate code number }} & \multirow{3}{*}{$\begin{array}{c}\begin{array}{c}\text { GenBank } \\
\text { accession } \\
\text { number }\end{array} \\
\text { MF471296 }\end{array}$} & \multirow{3}{*}{$\begin{array}{c}\text { Phylum } \\
\text { Ascomycota }\end{array}$} & \multirow{3}{*}{$\begin{array}{l}\text { Possible identity } \\
\text { Pestalotiopsis }\end{array}$} & \multicolumn{2}{|c|}{$\begin{array}{c}\text { Best match in BLAST } \\
\text { analysis }\end{array}$} & \multirow{3}{*}{$\begin{array}{c}\text { Host Substrate of } \\
\text { P. coriacardia }\end{array}$} \\
\hline & & & & & \multirow{2}{*}{$\begin{array}{c}\begin{array}{c}\text { Closest } \\
\text { relatives } \\
\text { (accession } \\
\text { number) }\end{array} \\
\text { AY461815.1 }\end{array}$} & \multirow{2}{*}{\begin{tabular}{|c|}
$\%$ Identity \\
99
\end{tabular}} & \\
\hline UCUE_Pc_M_ & $1 \mathrm{MF5}$ & & & & & & \\
\hline UCUE_Pc_M_ & $1 \mathrm{MF} 1$ & MF471251 & Ascomycota & Nigrospora & EU272503.1 & 99 & Other phorophytes \\
\hline UCUE_Pc_M_ & $1 \mathrm{MF} 2$ & MF471234 & Basidiomycota & Psilocybe & KC007301.1 & 96 & Other phorophytes \\
\hline UCUE_Pc_M_ & $1 \mathrm{MF} 6$ & MF471289 & Basidiomycota & Unknown fungi & KU761146.1 & 94 & Other phorophytes \\
\hline UCUE_Pc_M_ & 2MR2 & MF471266 & Ascomycota & Arthrinium & HQ385968.1 & 98 & Rock \\
\hline UCUE_Pc_M_ & 2MF4 & MF471247 & Zygomycota & Helicostylum & KM396375.1 & 95 & Rock \\
\hline UCUE_Pc_M_ & 3MR1 & MF471265 & Ascomycota & Trichoderma & KU727807.1 & 99 & Rock \\
\hline UCUE_Pc_M_ & 3MR3 & MF471253 & Ascomycota & Hypocrea & EU871036 & 99 & Rock \\
\hline UCUE_Pc_M_ & 3MR5 & MF471248 & Ascomycota & Trichoderma & JF773644 & 99 & Rock \\
\hline UCUE_Pc_M_ & 3MR2 & MF471252 & Ascomycota & Unknown fungi & KP714312.1 & 85 & Rock \\
\hline UCUE_Pc_M_ & 5.1MF7 & MF471228 & Basidiomycota & Coprinellus & FJ185160.1 & 99 & $\begin{array}{l}\text { Phorophytes in } \\
\text { decomposition }\end{array}$ \\
\hline UCUE_Pc_M_ & $5.1 \mathrm{MF} 1$ & MF471278 & Basidiomycota & Mycena & FJ785523.1 & 96 & $\begin{array}{l}\text { Phorophytes in } \\
\text { decomposition }\end{array}$ \\
\hline UCUE_Pc_M_ & $5 \mathrm{MF} 2$ & MF471303 & Ascomycota & Trichoderma & HM439523.1 & 95 & $\begin{array}{l}\text { Phorophytes in } \\
\text { decomposition }\end{array}$ \\
\hline UCUE_Pc_M_ & $6 \mathrm{MF3}$ & MF471236 & Ascomycota & Ilyonectria & KF646096.1 & 99 & $\begin{array}{l}\text { Phorophytes in } \\
\text { decomposition }\end{array}$ \\
\hline UCUE_Pc_M_ & 7MR5 & MF471241 & Ascomycota & Gibberella & HQ630977 & 99 & Rock \\
\hline UCUE_Pc_M_ & 7MR4 & MF471304 & Basidiomycota & Psathryrellaceae & GU056021 & 96 & Rock \\
\hline UCUE_Pc_M_ & 8MF4 & MF471270 & Ascomycota & Trichoderma & KU727807.1 & 99 & Other phorophytes \\
\hline UCUE_Pc_M_ & $8 \mathrm{MF} 2$ & MF471238 & Ascomycota & Endophyte & FJ613085.1 & 99 & Other phorophytes \\
\hline UCUE_Pc_M_ & 8MF5 & MF471268 & Ascomycota & Unknown fungi & KU978069.1 & 94 & Other phorophytes \\
\hline UCUE_Pc_M_ & $9.1 \mathrm{MF} 3$ & MF471245 & Ascomycota & Fusarium & KU978069.1 & 99 & $\begin{array}{l}\text { Phorophytes in } \\
\text { decomposition }\end{array}$ \\
\hline UCUE_Pc_M_ & 9.3MF1 & MF471246 & Zygomycota & Umbelopsis & AB193542.1 & 98 & $\begin{array}{l}\text { Phorophytes in } \\
\text { decomposition }\end{array}$ \\
\hline UCUE_Pc_M_ & 9.3MF2 & MF471222 & Basidiomycota & Coprinellus & FJ185160.1 & 98 & $\begin{array}{l}\text { Phorophytes in } \\
\text { decomposition }\end{array}$ \\
\hline UCUE_Pc_M_ & 9.2MF2 & MF471231 & Ascomycota & Unknown fungi & AM999730 & 85 & $\begin{array}{l}\text { Phorophytes in } \\
\text { decomposition }\end{array}$ \\
\hline UCUE_Pc_M_ & 9.3MF4 & MF471238 & Ascomycota & Unknown fungi & FJ613085.1 & 80 & $\begin{array}{l}\text { Phorophytes in } \\
\text { decomposition }\end{array}$ \\
\hline UCUE_Pc_M_ & $10 \mathrm{MF} 4$ & MF471261 & Ascomycota & Nectriaceae & JN088237.1 & 99 & Other phorophytes \\
\hline UCUE_Pc_M_ & $10 \mathrm{MF} 2$ & MF471242 & Ascomycota & Bionectria & KC007301.1 & 96 & Other phorophytes \\
\hline UCUE_Pc_M_ & $10 \mathrm{MF} 1$ & MF471260 & Ascomycota & Unknown fungi & FR717914.1 & 81 & Other phorophytes \\
\hline UCUE_Pc_M_ & 12.1MF3 & Unidentified & Basidiomycota & Unknown fungi & Unidentified & - & $\begin{array}{l}\text { Phorophytes in } \\
\text { decomposition }\end{array}$ \\
\hline UCUE_Pc_M_ & $12 \mathrm{MF3}$ & MF471300 & Ascomycota & Xylaria & KU743974.1 & 99 & Ocotea sp. \\
\hline UCUE_Pc_M_ & $12 \mathrm{MF} 6$ & MF471291 & Ascomycota & Epicoccum & HQ914878 & 99 & Ocotea sp. \\
\hline UCUE_Pc_M_ & $12 \mathrm{MF} 2$ & MF471279 & Ascomycota & Epicoccum & KX664321.1 & 99 & Ocotea sp. \\
\hline
\end{tabular}




\begin{tabular}{|c|c|c|c|c|c|c|c|}
\hline UCUE_Pc_M_ & 12.1MF4 & MF471282 & Ascomycota & Trichoderma & JN715591.1 & 98 & $\begin{array}{l}\text { Phorophytes in } \\
\text { decomposition }\end{array}$ \\
\hline UCUE_Pc_M_ & 14MF2 & MF471299 & Ascomycota & Fusarium & KU978069.1 & 99 & $\begin{array}{l}\text { Sarar - Weinmannia } \\
\text { fagaroides }\end{array}$ \\
\hline UCUE_Pc_M_ & 17MR4 & MF471263 & Ascomycota & Chaetomium & HG937119.1 & 98 & Rock \\
\hline UCUE_Pc_M_ & 18.1MF3 & MF471240 & Basidiomycota & Coprinellus & JN198387 & 99 & Ocotea sp. \\
\hline UCUE_Pc_M_ & $18 \mathrm{MF} 4$ & MF471220 & Ascomycota & Phoma & EU343130 & 99 & Ocotea sp. \\
\hline UCUE_Pc_M_ & 19MF2 & MF471226 & Basidiomycota & Coprinellus & JN198387 & 97 & $\begin{array}{l}\text { Sarar - Weinmannia } \\
\text { fagaroides }\end{array}$ \\
\hline UCUE_Pc_M_ & 19MF1.4.1 & MF471221 & Basidiomycota & Unknown fungi & GU055721 & 90 & $\begin{array}{l}\text { Sarar - Weinmannia } \\
\text { fagaroides }\end{array}$ \\
\hline UCUE_Pc_M_ & $20 \mathrm{M} 6$ & MF471243 & Ascomycota & Chaetomium & HG937119.1 & 99 & Ocotea $s p$ \\
\hline UCUE_Pc_M_ & $21 \mathrm{MF} 2$ & MF471254 & Basidiomycota & Coprinellus & FJ755223 & 99 & Ocotea sp. \\
\hline UCUE_Pc_M_ & $21 \mathrm{MF} 1$ & MF471232 & Basidiomycota & Coprinellus & KP216899.1 & 99 & Ocotea sp. \\
\hline UCUE_PC_M_ & $21 \mathrm{MF} 4$ & MF471250 & Basidiomycota & Coprinellus & FJ755223 & 98 & Ocotea sp. \\
\hline UCUE_PC_M_ & 22MF & MF471305 & Zygomycota & Umbelopsis & EU490082 & 98 & Other phorophytes \\
\hline UCUE_Pc_M_ & $22 \mathrm{MF} 2.3$ & MF471294 & Basidiomycota & Coprinellus & AY461815.1 & 95 & Other phorophytes \\
\hline UCUE_Pc_M_ & 22MF3 & MF471237 & Zygomycota & Unknown fungi & AB193543.1 & 90 & Other phorophytes \\
\hline UCUE_Pc_M_ & 23MF3 & MF471244 & Zygomycota & Unknown fungi & KJ028792.1 & 93 & $\begin{array}{l}\text { Sarar - Weinmannia } \\
\text { fagaroides }\end{array}$ \\
\hline UCUE_PC_M_ & $24 \mathrm{MF} 1$ & MF471293 & Zygomycota & Absidia & AY944874 & 96 & Ocotea sp. \\
\hline UCUE_Pc_M_ & 24MF2 & MF471269 & Ascomycota & Unknown fungi & KU978069.1 & 94 & Ocotea $s p$ \\
\hline UCUE_Pc_M_ & 25MF1 & MF471301 & Basidiomycota & Coprinellus & KT804053.1 & 96 & $\begin{array}{l}\text { Sarar - Weinmannia } \\
\text { fagaroides }\end{array}$ \\
\hline UCUE_Pc_M_ & 26MF1 & MF471281 & Ascomycota & Hypocrea & EF488156.1 & 99 & $\begin{array}{l}\text { Phorophytes in } \\
\text { decomposition }\end{array}$ \\
\hline UCUE_Pc_M_ & 27MFA & MF471259 & Ascomycota & Fusarium & KU377445.1 & 99 & $\begin{array}{l}\text { Phorophytes in } \\
\text { decomposition }\end{array}$ \\
\hline UCUE_Pc_M_ & $27 \mathrm{MF}$ & MF471277 & Basidiomycota & Coprinellus & KU761146.1 & 98 & $\begin{array}{l}\text { Phorophytes in } \\
\text { decomposition }\end{array}$ \\
\hline UCUE_Pc_M_ & 27MF3 & MF471264 & Ascomycota & Unknown fungi & FJ449935 & 92 & $\begin{array}{l}\text { Phorophytes in } \\
\text { decomposition }\end{array}$ \\
\hline UCUE_Pc_M_ & 28MFN1 & MF471292 & Ascomycota & Trichoderma & HМ037962.1 & 99 & $\begin{array}{l}\text { Phorophytes in } \\
\text { decomposition }\end{array}$ \\
\hline UCUE_Pc_M_ & 29MF2.8 & MF471274 & Ascomycota & Fusarium & KU978069.1 & 99 & $\begin{array}{c}\text { Arrayán - Myrcianthes } \\
\text { rhopaloides }\end{array}$ \\
\hline UCUE_Pc_M_ & 29MF2.3.1 & MF471267 & Ascomycota & Cercosporidium & EU543257 & 99 & $\begin{array}{c}\text { Arrayán - Myrcianthes } \\
\text { rhopaloides }\end{array}$ \\
\hline UCUE_Pc_M_ & 29MF4 & MF471286 & Ascomycota & Cylindrocladium & KR780039.1 & 98 & $\begin{array}{c}\text { Arrayán - Myrcianthes } \\
\text { rhopaloides }\end{array}$ \\
\hline UCUE_Pc_M_ & 29MF9 & MF471285 & Ascomycota & Fusarium & FJ545374.1 & 98 & $\begin{array}{c}\text { Arrayán - Myrcianthes } \\
\text { rhopaloides }\end{array}$ \\
\hline UCUE_Pc_M_ & 29MF2.7 & MF471271 & Ascomycota & Sordariomycetes & FJ449913 & 98 & $\begin{array}{l}\text { Arrayán - Myrcianthes } \\
\text { rhopaloides }\end{array}$ \\
\hline UCUE_Pc_M_ & 29MF2.2 & MF471235 & Basidiomycota & Psilocybe & AJ519795.1 & 98 & $\begin{array}{c}\text { Arrayán - Myrcianthes } \\
\text { rhopaloides }\end{array}$ \\
\hline UCUE_Pc_M_ & 29MF2.5.1 & MF471306 & Ascomycota & Diaporthe & EU272520 & 97 & $\begin{array}{c}\text { Arrayán - Myrcianthes } \\
\text { rhopaloides }\end{array}$ \\
\hline UCUE_Pc_M_ & 30MR6 & MF471307 & Ascomycota & Fusarium & GQ229075 & 97 & Rock \\
\hline UCUE_Pc_M_ & 30MR2.2 & MF471290 & Ascomycota & Sordariomycetes & JQ761706 & 95 & Rock \\
\hline UCUE_PC_M_ & 31MF1 & MF471262 & Ascomycota & Endophyte & AY561198.1 & 95 & $\begin{array}{c}\text { Arrayán - Myrcianthes } \\
\text { rhopaloides }\end{array}$ \\
\hline UCUE_Pc_M_ & $31 \mathrm{MF} 2.2$ & MF471288 & Ascomycota & Unknown fungi & KX650836.1 & 81 & $\begin{array}{c}\text { Arrayán - Myrcianthes } \\
\text { rhopaloides }\end{array}$ \\
\hline UCUE_Pc_M_ & 32MF5 & MF471264 & Ascomycota & Nectriaceae & KU978069.1 & 99 & $\begin{array}{l}\text { Arrayán - Myrcianthes } \\
\text { rhopaloides }\end{array}$ \\
\hline UCUE_Pc_M_ & 32MF4 & MF471256 & Ascomycota & Fusarium & AY745988 & 99 & $\begin{array}{c}\text { Arrayán - Myrcianthes } \\
\text { rhopaloides }\end{array}$ \\
\hline
\end{tabular}




\begin{tabular}{|c|c|c|c|c|c|c|c|}
\hline UCUE_Pc_M_ & 32MF6 & MF471280 & Basidiomycota & Coprinellus & FJ185160.1 & 97 & $\begin{array}{c}\text { Arrayán - Myrcianthes } \\
\text { rhopaloides }\end{array}$ \\
\hline UCUE_Pc_M_ & 32MF2.1 & MF471308 & Ascomycota & Endophyte & HQ889707 & 96 & $\begin{array}{l}\text { Arrayán - Myrcianthes } \\
\text { rhopaloides }\end{array}$ \\
\hline UCUE_Pc_M_ & 32MF3 & MF471239 & Basidiomycota & Coprinellus & AB176569.1 & 91 & $\begin{array}{c}\text { Arrayán - Myrcianthes } \\
\text { rhopaloides }\end{array}$ \\
\hline UCUE_Pc_M_ & 33MF2.3 & MF471297 & Ascomycota & Hymenoscyphus & GU479911.1 & 99 & $\begin{array}{c}\text { Arrayán - Myrcianthes } \\
\text { rhopaloides }\end{array}$ \\
\hline UCUE_Pc_M_ & $33 \mathrm{MF} 2.1$ & MF471283 & Basidiomycota & Trametes & KX056103.1 & 99 & $\begin{array}{c}\text { Arrayán - Myrcianthes } \\
\text { rhopaloides }\end{array}$ \\
\hline UCUE_Pc_M_ & 33MF2.4 & MF471275 & Ascomycota & Nectriaceae & KU978069.1 & 99 & $\begin{array}{c}\text { Arrayán - Myrcianthes } \\
\text { rhopaloides }\end{array}$ \\
\hline UCUE_Pc_M_ & 33MF2.2 & MF471309 & Basidiomycota & Gelatoporia & FN907911 & 97 & $\begin{array}{c}\text { Arrayán - Myrcianthes } \\
\text { rhopaloides }\end{array}$ \\
\hline UCUE_Pc_M_ & 35MF4 & MF471258 & Ascomycota & Fusarium & AY745988 & 99 & $\begin{array}{c}\text { Arrayán - Myrcianthes } \\
\text { rhopaloides }\end{array}$ \\
\hline UCUE_Pc_M_ & $35 \mathrm{MF} 1$ & MF471257 & Ascomycota & Fusarium & AY745988 & 99 & $\begin{array}{c}\text { Arrayán - Myrcianthes } \\
\text { rhopaloides }\end{array}$ \\
\hline
\end{tabular}

